\title{
Land use impacts on soil erosion and rejuvenation in Southern Brazil
}

\author{
Veerle Vanacker ${ }^{\mathrm{a}}$, Yolanda Ameijeiras-Mariño ${ }^{\mathrm{b}}$, Jerome Schoonejans ${ }^{\mathrm{a}}$, Jean-Thomas Cornélis ${ }^{\mathrm{c}}$ \\ Jean P.G. Minella ${ }^{\mathrm{d}}$, Florence Lamouline ${ }^{\mathrm{b}}$, Marie-Liesse Vermeire ${ }^{\mathrm{b}}$, Benjamin Campforts ${ }^{\mathrm{e}}$, \\ Jeremy Robinet ${ }^{\mathrm{e}}$, Marijn Van de Broek ${ }^{\mathrm{e}, 1}$, Pierre Delmelle ${ }^{\mathrm{b}}$, Sophie Opfergelt $\mathrm{t}^{\mathrm{b}, *}$ \\ ${ }^{\text {a }}$ Earth and Life Institute, George Lemaître Center for Earth and Climate Research, Université catholique de Louvain, L4.03.08, 1348 Louvain-la-Neuve, Belgium \\ ${ }^{\mathrm{b}}$ Earth and Life Institute, Environmental Sciences, Université catholique de Louvain, L7.05.10, 1348 Louvain-la-Neuve, Belgium \\ ${ }^{\mathrm{c}}$ Biosystem Engineering Department, Gembloux Agro-Bio Tech, Université de Liége, Passage des Déportés, 2, 5030 Gembloux, Belgium \\ d Department of Soils, Federal University of Santa Maria, 97105-900 Santa Maria, Brazil \\ ${ }^{\mathrm{e}}$ Department of Earth and Environmental Sciences, KU Leuven, Celestijnenlaan 200 E, 3001 Leuven, Belgium
}

\section{A R T I C L E I N F O}

\section{Keywords:}

Soil weathering degree

Toposequence

Soil rejuvenation

Forest conversion

Anthropogenic soil erosion

Subtropical climate

\begin{abstract}
A B S T R A C T
Topography is one of the key factors controlling soil erosion and redistribution of pedogenic material along slope. Land cover change can have an accelerating or retarding impact on topographically-controlled soil erosion rates, depending on the type and intensity of land use and management. In this study, we investigated the combined effect of hillslope gradient and land cover change on soil redistribution and rejuvenation in a subtropical region where Atlantic rain forest was converted to agricultural land. We used a two versus two factorial design, and evaluated the effect of hillslope gradient (steep vs. gentle) and land cover (forest vs. cropland) on the spatial pattern of soil weathering degree along slope. In four soil toposequences, soil weathering indices (Total Reserve in Bases, Chemical Index of Alteration, clay content, iron oxide content) and mineralogical assemblages were used to express genetic and morphological differences among soil profiles. Our data showed that the spatial differentiation in chemical weathering degree along slope is strongly dependent on the hillslope gradient: while the gentle slopes show negligible differences in chemical weathering degree along slope, the steep slopes show clear spatial differences. Besides, there is an interaction effect between hillslope gradient and land cover. Forest conversion to cropland enhances erosion-driven soil redistribution with a marked effect on soil rejuvenation along steep slopes but no clear effect along gentle slopes. The comparative study based on four toposequences highlights that accelerated soil erosion after conversion of forests to cropland has further enhanced lateral soil fluxes and redistribution of topsoil material along steep slopes, and led to soil rejuvenation and exposure of less weathered soil material at the eroding sites.
\end{abstract}

\section{Introduction}

The conversion of forests to arable land enables an expansion of the area available for food production, but also brings profound changes to the functioning of terrestrial ecosystems (Foley et al., 2005; Foley, 2011). The potential impact of agricultural activities on tropical and subtropical soils is of particularly concern because of their low mineral nutrient reserve (Godfray et al., 2010; Foley, 2011). In humid tropical and subtropical environments, soils are characterised by intense chemical weathering and leaching of soluble components (e.g., Chadwick et al., 2003; Hewawasam et al., 2013; Molina et al., 2019). The development of the soil mantle is the result of in-situ weathering, atmospheric input and downhill transport of weathering products (Carson and Kirkby, 1972; Mudd and Furbish, 2006). Lateral transport of soil particles, aggregates and solutes by diffusive and concentrated particle and solute fluxes result in lateral redistribution of weathering products over the hillslope (Schoonejans et al., 2016). The redistribution of pedogenic material along slopes is highly dependent on its

\footnotetext{
* Corresponding author.

E-mail addresses: veerle.vanacker@uclouvain.be (V. Vanacker), yolanda.ameijeiras@uclouvain.be (Y. Ameijeiras-Mariño), jerome.schoonejans@uclouvain.be (J. Schoonejans), jtcornelis@ulg.ac.be (J.-T. Cornélis), jminella@smail.ufsm.br (J.P.G. Minella),

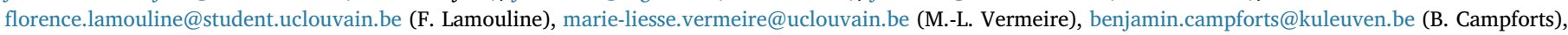
jeremy.robinet@kuleuven.be (J. Robinet), marijn.vandebroek@usys.ethz.ch (M. Van de Broek), pierre.delmelle@uclouvain.be (P. Delmelle), sophie.opfergelt@uclouvain.be (S. Opfergelt).

${ }^{1}$ Present address: ETH Zürich.
} 


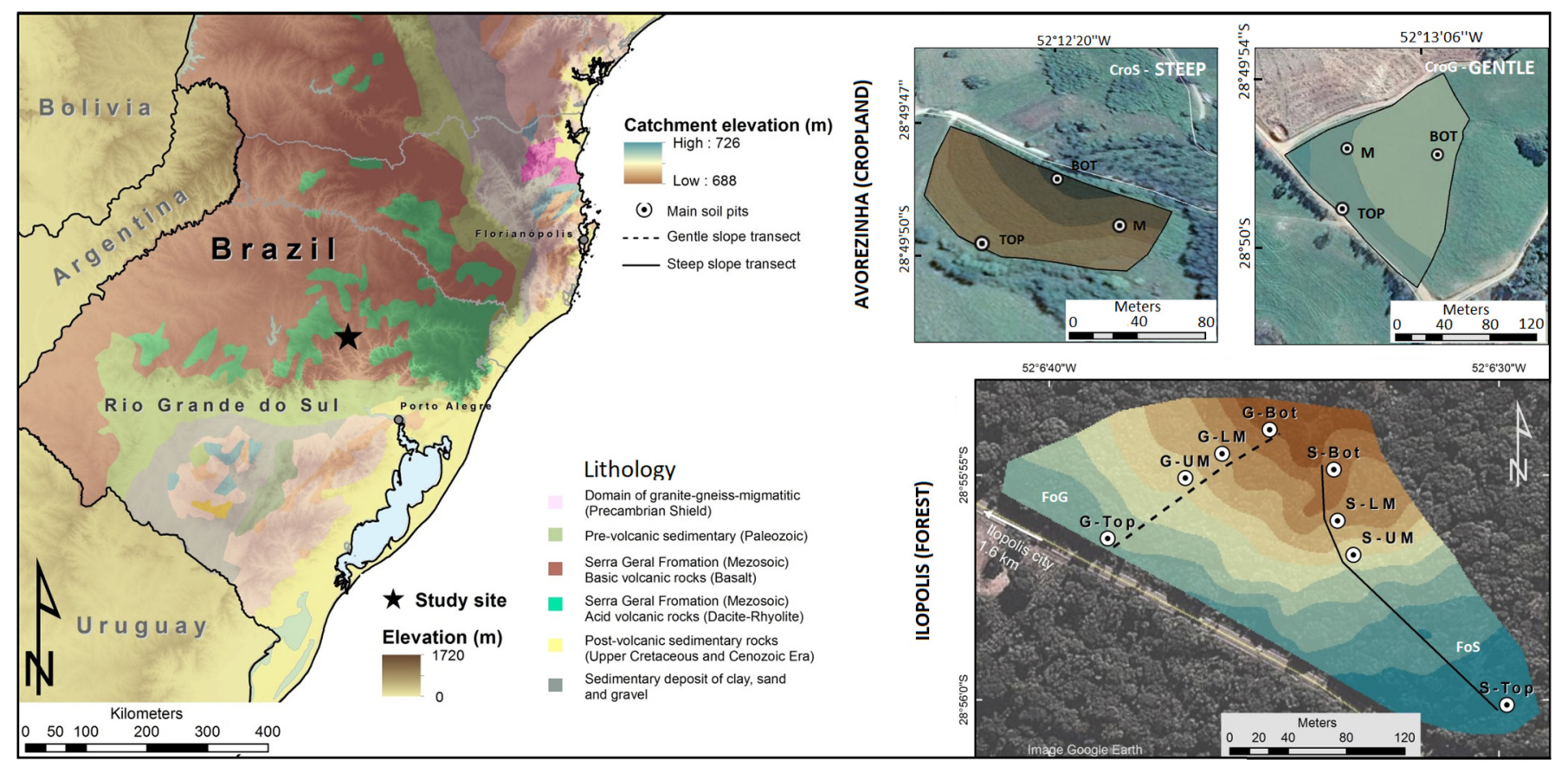

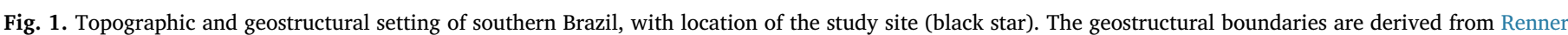

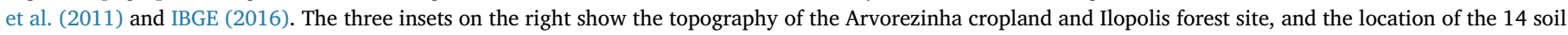
pits along the four toposequences.

hillslope gradient and topographic position (Hall, 1983; Vitousek et al., 2003; Chadwick and Asner, 2016). Burke et al. (2007) showed that the spatial variation in soil weathering degree along soil-mantled hillslopes is topographically controlled, with lower soil weathering degree in steep compared to gentle slopes. In a study by Chadwick and Asner (2016) in the southern Peruvian Amazon, the rock-derived nutrient distributions across the heterogeneous landscape were associated with topographic gradients, leading them to conclude that geomorphic processes play a major role in the rejuvenation of rock-derived nutrients in soil systems.

Forest conversion for agriculture may have diverse direct and indirect consequences on soil physico-chemical properties, and their variation over the hillslopes, due to changes in plant-soil interactions and nutrient exchange, agricultural practices, soil hydrology and geomorphic process rates. Anthropogenic land cover change modifies the nutrient uptake by plants and rhizosphere processes and may influence mineral weathering directly (e.g., Baker, 1973; Schnitzer and Kodama, 1976; Drever, 1994; Lucas, 2001; Velde and Meunier, 2008; McGahan et al., 2014). Through the input of fertilisers, agricultural practices may affect soil acidity and clay mineralogy (e.g., Barak et al., 1997; Velde and Peck, 2002; Velde and Meunier, 2008; Simonsson et al., 2009; Cornu et al., 2012; Matocha et al., 2016; Moterle et al., 2016), with potential implications on soil mineral weathering. On annual to decadal time scales, the direct effects of cropping systems and agricultural practices on soil physico-chemical properties are likely to be overtaken by its indirect effects. Soil hydrology and soil water availability tend to change after deforestation (e.g., Bosch and Hewlett, 1982; Molina et al., 2015), because of e.g. the lower evapotranspiration in grasslands or croplands relative to forests (e.g., Foley et al., 2003), with indirect effects on nutrient leaching along hillslopes. Besides, physical erosion rates in agricultural soils are - on average - one order of magnitude higher than in forested soils (Hooke, 2000; Wilkinson, 2005; Montgomery, 2007; Vanacker et al., 2007; Cerdan et al., 2010; Reusser et al., 2015). At eroding sites, the highly weathered topsoil is replaced by subsurface soil material, potentially leading to erosion-driven soil rejuvenation. Agricultural practices, such as soil tillage, enhance downslope transport of eroded soil particles and soil redistribution along slopes, and further increase the within-field variation in soil weathering degree (Govers et al., 1996; Van Oost et al., 2006).

Existing field-based studies on soil weathering have often focused on rock-derived soil nutrient distributions across hillslopes in natural ecosystems, and analysed the complex interplay that exists between vegetation growth, soil hydrology, physical erosion and soil evolution (Chadwick et al., 2003; Dixon et al., 2016). By focusing on well-preserved environments, anthropogenic alterations of the soil-landscape system cannot be assessed. In anthropogenic environments such as agricultural landscapes, soil physico-chemical properties evolve dynamically along slopes in response to anthropogenically altered soil hydrology and geomorphic process rates (e.g., Khormali et al., 2009; Bortoluzzi et al., 2012; Poesen, 2018) and accelerated soil erosion rates led to extensive anthropogenic terrestrial sedimentary deposits (Chin et al., 2013; James, 2013).

This study aims to analyse the influence of slope morphology and land use on soil physico-chemical properties, and on the spatial distribution of soil nutrients along slopes. Soil-landscapes in deeply weathered subtropical environments are particularly suitable, as recent forest conversion to arable land has led to an increase in soil erosion rates (Merten and Minella, 2006; Vanacker et al., 2014; Restrepo et al., 2015). We investigated the combined effect of geomorphology and land use on soil redistribution and rejuvenation in a subtropical region where the majority of Atlantic rain forest was converted to agricultural land in the 1960s (Minella, 2003; Minella et al., 2008). Our study is part of a larger project on soil systems on global change, where a forested and agricultural catchment in the Guapore river basin in Southern Brazil were studied for short- and long-term soil-landscape dynamics (Ameijeiras-Mariño et al., 2018; Robinet et al., 2018a, 2018b; UnzuéBelmonte et al., 2017; Schoonejans et al., 2017).

In the Guaporé study sites, we used a two by two study design, and evaluated the effect of hillslope gradient (steep vs. gentle) and land cover (humid subtropical forest vs. cropland) on the spatial pattern of soil weathering degree along slope. The two sites in the humid subtropical forest can be considered as the control sites, representative for soil development and evolution along steep ( $>13^{\circ}$ slope gradient) and gentle $\left(<9^{\circ}\right.$ slope gradient) hillslopes in natural forests. The soil 
Cropland - Steep slope (CroS)

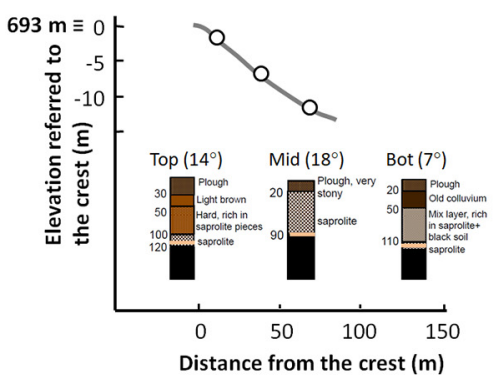

Forest - Steep slope (FoS)
Cropland - Gentle slope (CroG)

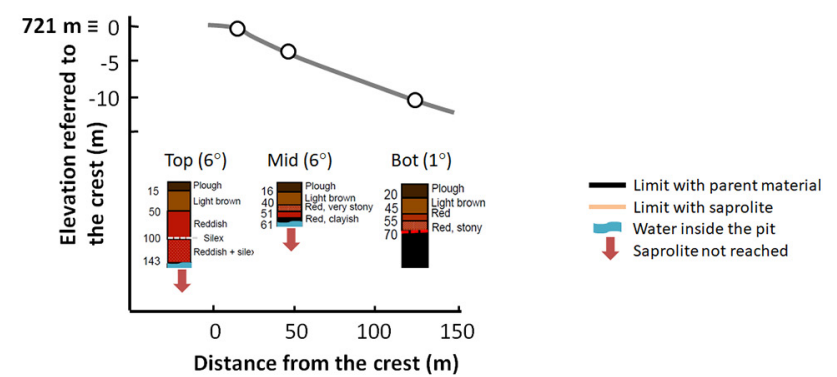

Forest - Gentle slope (FoG)

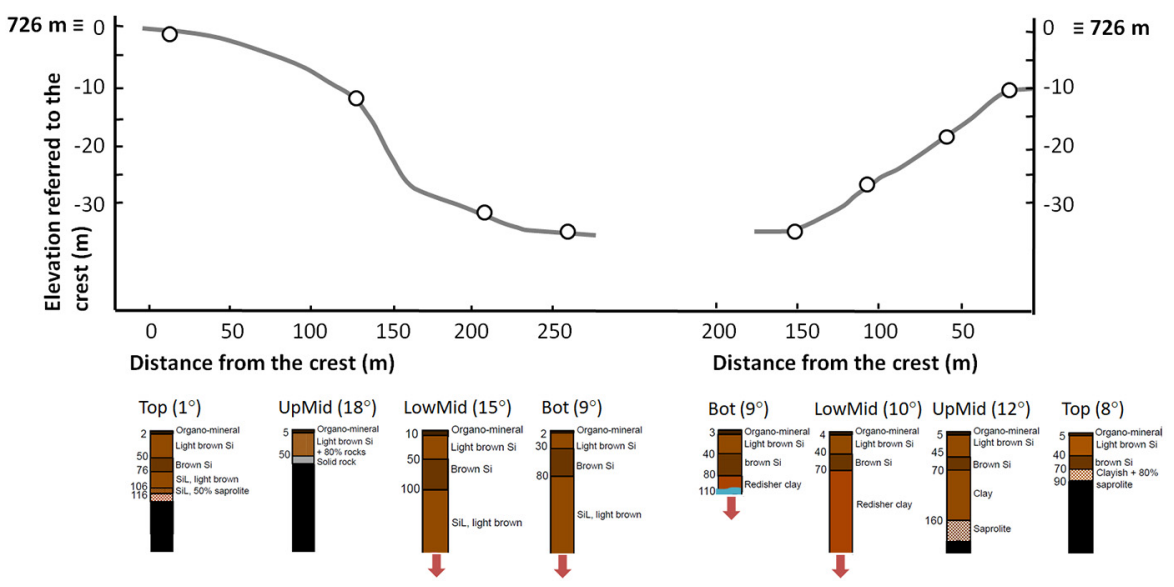

Fig. 2. Main geomorphological characteristics of the four toposequences, with indication of the soil profile descriptions.

physico-chemical properties of the two forested sites can then be contrasted with the corresponding data from the steep and gentle slopes of the agricultural sites to observe the effect of land use and slope gradient on soil redistribution and rejuvenation. In this study, we posit that the weathering degree of the soil mantle differs between slopes with (i) gentle and steep topographic gradients and (ii) land use history.

\section{Study site}

In the headwaters of the Guaporé river basin in Southern Brazil, we selected two small catchments with contrasting land use. The catchments are located $15 \mathrm{~km}$ apart, on the edge of the Rio-Grandense or Southern Brazilian plateau (Fig. 1). Hereafter, they are referred to as the Arvorezinha and Ilopolis catchment, from the names of the nearby cities. Both of them are located on the southern border of the so-called Serra Gerral formation belonging to the Parana Magmatic Province described in Bellieni et al. (1986) and Montanheiro et al. (2004). Their lithology is similar, as they are underlain by rhyodacitic bedrock with aphanitic texture with 69 to $71 \mathrm{wt} \%$ of $\mathrm{SiO}_{2},<0.87 \mathrm{wt} \%$ of $\mathrm{TiO}_{2}$ and $<0.21$ wt $\%$ of $\mathrm{P}_{2} \mathrm{O}_{5}$ (Vieira et al., 2015; Schoonejans et al., 2017). The bedrock mineralogy is dominated by sanidine and fine grained quartz. The upper parts of the two catchments have gentle rolling topography with mean slope gradients between 2 and $8 \%$, while the lower parts typically have short and steeper slopes with mean slope gradients of 15 to $20 \%$. The dominant soil types following the IUSS Working Group WRB (2007) are Acrisols, with Cambisols and Leptosols on the eroded slopes (Minella et al., 2009). The climate is classified as subtropical super-humid mesothermic (Minella et al., 2008). For the period 2002-2017, the average monthly temperature was $12^{\circ} \mathrm{C}$ in July and $22^{\circ} \mathrm{C}$ in January, and the mean annual rainfall was $1944 \pm 336 \mathrm{~mm}$ (Robinet et al., 2018b).

Atlantic forest initially covered the area, and extended from the
Atlantic coast of Brazil to its inland (Morellato and Haddad, 2000). The semi-deciduous subtropical forest has Araucaria angustifolia, Luehea divaricata, Nectandra Grandiflora and Campomanesia guaviroba as the dominant species. The Ilopolis catchment, covered by subtropical forest $\left(0.03 \mathrm{~km}^{2}\right)$, is located in a small remnant of the original Atlantic forest. Large-scale forest conversion to cropland started in Rio Grande do Sul in the beginning of the 20th century, and reached its peak in the early 1960s with the introduction of tobacco and soybean cash crops (Lopes, 2006; Minella et al., 2008). The Arvorezinha catchment is covered by arable land that is used for cultivating tobacco (Nicotiana tabacum), soybean (Glycine max), maize (Zea mays), black oats (Avena strigose), and erva-mate (Ilex paraguariensis). The decline in soil productivity because of accelerated soil losses resulted in an intensive use of chemical fertilisers and pesticides (Merten and Minella, 2006). To reduce soil losses and water pollution by sediment, phosphorus and nitrogen, rural extension agencies launched soil conservation programs in the 1990s to encourage farmers to adopt soil conservation practices and minimum tillage systems (Minella et al., 2008). In 2016, the farmers typically applied $850 \mathrm{~kg} \mathrm{ha}^{-1} \mathrm{yr}^{-1}$ of NPK (10-18-20) during seed planting, $400 \mathrm{~kg} \mathrm{ha}^{-1} \mathrm{yr}^{-1}$ of nitrate $\left(\mathrm{NaNO}_{3}\right)$ at 45 days after planting, and $400 \mathrm{~kg} \mathrm{ha}^{-1} \mathrm{yr}^{-1}$ of lime $\left(65 \% \mathrm{CaCO}_{3}\right)$ to their fields.

\section{Methods}

\subsection{Sampling}

Within the two catchments, Arvorezinha and Ilopolis, two toposequences with different slope morphology were selected for the soil landscape analysis: a steep slope with average slope gradient of $13^{\circ} \pm 2^{\circ}$ in forest and $14 \pm 4^{\circ}$ in cropland, and a gentle slope with average slope gradient of $9 \pm 2^{\circ}$ in forest and $6 \pm 1^{\circ}$ in cropland (Fig. 1). The location of the sites was determined with a Trimble 
GeoExplorer 2008 XT GPS (with overall precision of $5 \mathrm{~m}$ ), and slope angles were measured with a SUUNTO inclinometer in the field. The soils on the gentle and steep forest slope and the gentle cropland slope were classified as Acrisols, and soils in the steep cropland slope as Leptosols according to the IUSS Working Group WRB (2007). Along the four toposequences, we excavated soil pits at the upslope, upper and/or lower middle and toeslope position. Our team described the soil profiles by horizons according to FAO guidelines (FAO, 2006), and they sampled soil and saprolite material at fixed depths down to the refusal layer or two meters depth. The appendix contains the full description of the profiles in Tables A2 to A5, and pictures of the soil profiles in Fig. 2. Bulk samples were taken in $10 \mathrm{~cm}$ intervals at fixed depths until the maximum depth possible. Soil samples were then air-dried and sieved at $2 \mathrm{~mm}$. Bedrock samples were collected from nearby outcrops at road cuts, where possible.

Schoonejans et al. (2017) derived long-term erosion rates for the upslope soil profiles in the native forest based on meteoric and in-situ produced ${ }^{10} \mathrm{Be}$ isotope concentrations. Surface erosion rates derived from corrected meteoric ${ }^{10} \mathrm{Be}$ inventories equal $5.0 \pm 0.5 \mathrm{~mm} \mathrm{kyr}{ }^{-1}$ and are in agreement with in-situ ${ }^{10} \mathrm{Be}$ derived erosion rates $(<5 \mathrm{~mm}$ $\mathrm{kyr}^{-1}$ ). The geochemical data from Schoonejans et al. (2017) showed that soil profiles in the upper parts of the landscape have been subject to deep and intense soil mixing over the last 10 kyrs. Given their very low surface erosion rates, the upslope soil profiles on the hilltop convexities approximate "reference" soil profiles, and we assume that their soil chemical and physical properties are mainly the result of autochtonous soil development.

\subsection{Soil physico-chemical characterisation}

Soil bulk density was measured at the same depths as the soil samples (Table A6) from an undisturbed soil sample taken with a $100 \mathrm{~cm}^{3}$ cylindrical ring and dried at $105^{\circ} \mathrm{C}$ before weighing. The particle size distribution was obtained by laser diffraction using a Coulter LS-100, and the clay-sized fraction was determined from the cumulative particle sizes of $<2 \mu \mathrm{m}$. Samples were prepared for laser diffractometry measurements by ultrasonic dispersion and removal of organic matter using hydrogen peroxide (35\%) following the procedure described in Beuselinck et al. (1998). In a recent study, Fisher et al. (2017) resume the main differences in measurement results between laser diffraction and sieve-pipette methods, that reflect the different physical principles used to describe the 3-dimensional particle shapes (Eshel et al., 2004). The soil pH was measured in de-ionised water with a ratio of $5 \mathrm{~g}$ of soil for $25 \mathrm{ml}$ of solution (Page et al., 1982). The cation exchange capacity (CEC) was measured through soil saturation with ammonium acetate $1 \mathrm{M}$ at $\mathrm{pH}$ 7, followed by desorption and quantification of the ammonia retained in soils (Page et al., 1982). The total element content in soils was measured by ICP-AES $(<3 \%$ uncertainty relative to the basaltic USGS standard material BHVO-2, included in each series of alkaline fusion) after digestion by lithium metaborate and tetraborate fusion at $1000{ }^{\circ} \mathrm{C}$ and recovery of the fusion bead in $\mathrm{HNO}_{3}$ $1 \mathrm{~N}$ (Chao and Sanzolone, 1992). The loss on ignition (LOI) was assessed at $1000^{\circ} \mathrm{C}$ and the total element content is expressed in reference to the soil dry weight at $105^{\circ} \mathrm{C}$. The total amount of Fe-oxides was quantified on a subset of samples (average reproducibility on replicates of $\pm 3.6 \%)$ through selective extraction of $\mathrm{Fe}\left(\mathrm{Fe}_{\mathrm{d}}\right)$ by Dithonite-Citrate-Bicarbonate (DCB; Mehra and Jackson, 1960), followed by ICPAES measurement of Fe.

\subsection{Soil mineralogical characterisation}

The mineralogy of a subset of 2 bedrock, 16 bulk soil samples and their respective clay-sized fraction was determined by X-ray diffraction (XRD, Cu Ka, Bruker, D8 Advance). The bedrock fragments and the bulk soil samples were finely crushed in an agate mortar and measured by XRD as powder. The clay-sized fraction of the 16 soil samples was recovered by granulometric separation and analysed by XRD after $\mathrm{K}^{+}$ and $\mathrm{Mg}^{2+}$ saturation, ethylene glycol solvation and thermal treatments at 300 and $550{ }^{\circ} \mathrm{C}$ (Robert and Tessier, 1974). The full laboratory procedure is given in Appendix A2. The mineralogical database of the EVAC software allowed us to identify the mineral assemblages, and the SIROQUANT@ V4 software was used for semi-quantification of the mineral content. SIROQUANT@ applies the Rietveld (1969) method and involves fitting the observed diffraction pattern with a synthetic pattern. The difference between the synthetic and observed pattern is minimized by an interactive optimisation procedure, where the goodness-of-fit of the model is measured by the $\chi^{2}$. The detection limit of a mineral varies between 2 and 5\% (Klug and Alexander, 1954; Moore and Reynolds, 1997).

\subsection{Tracers of weathering and soil development}

The weathering degree was here assessed using a multiproxy approach (Ameijeiras-Mariño et al., 2017) that is based on the determination of the extent of soil chemical weathering from (1) the ratio of iron oxides extracted with DCB to total iron $\left(\mathrm{Fe}_{\mathrm{d}} / \mathrm{Fe}_{\mathrm{t}}\right)$, (2) the clay content (3) the Chemical Index of Alteration (CIA), (4) the Total Reserve in Bases (TRB), and (5) the mineralogical composition of selected soil samples. The $\mathrm{Fe}_{\mathrm{d}} / \mathrm{Fe}_{\mathrm{t}}$ represents the proportion of free iron among the total iron. As weathering advances, ferrous iron in primary minerals is released and oxidised and, hence, the ratio $\mathrm{Fe}_{\mathrm{d}} / \mathrm{Fe}_{\mathrm{t}}$ is expected to increase (Mehra and Jackson, 1960). The clay content (clay-sized fraction $<2 \mu \mathrm{m}$, expressed in \%) is expected to increase as weathering advances and clay minerals are formed, although this can also occur through clay migration in the soil profile and transport of clay particles along slope. The quartz content of the bulk soil can provide some information on the overall soil weathering degree given that quartz is resistant to weathering and its proportion increases in soils as a function of time and mineral weathering. The Chemical Index of Alteration, CIA (dimensionless), evaluates the mobility of the cations $\mathrm{Ca}^{+2}, \mathrm{~K}^{+}$and $\mathrm{Na}^{+}$in reference to $\mathrm{Al}^{+3}$ as a result of formation of clay minerals from feldspar weathering products (Nesbitt and Young, 1982; Nesbitt and Young, 1989; Fedo et al., 1995; Shao et al., 2012). It is calculated with Eq. (2) based on the elemental concentration of the samples (expressed in molar concentrations) and increases as weathering advances.

$\mathrm{CIA}=100 \times \frac{\mathrm{Al}_{2} \mathrm{O}_{3}}{\mathrm{Al}_{2} \mathrm{O}_{3}+\mathrm{CaO}+\mathrm{Na}_{2} \mathrm{O}+\mathrm{K}_{2} \mathrm{O}}$

The Total Reserve in Bases, TRB $\left(\mathrm{cmol}_{\mathrm{c}} \mathrm{kg}^{-1}\right)$ represents the sum of the total amount of alkaline and alkaline-earth elements $\left(\mathrm{Ca}^{+2}, \mathrm{~K}^{+}\right.$, $\mathrm{Mg}^{+2}, \mathrm{Na}^{+}$). It is calculated using Eq. (2) based on the elemental concentration of the samples obtained by alkaline fusion. Relative to the parent material, the TRB in soil decreases with increasing weathering as the soil chemical weathering results in a removal of mobile $\mathrm{Ca}$, $\mathrm{K}, \mathrm{Mg}$ and $\mathrm{Na}$ cations from the soil matrix (Herbillon, 1986).

$\mathrm{TRB}=\mathrm{Ca}^{+2}+\mathrm{K}^{+}+\mathrm{Mg}^{+2}+\mathrm{Na}^{+}\left(\mathrm{cmol}_{\mathrm{c}} \mathrm{kg}^{-1}\right)$

As the latter two indices, CIA and TRB of bulk soil, can be affected by nutrient input from agricultural management, we estimated the potential contribution of fertilisers to the soil cation content using the method described in Appendix A1.

\section{Results}

\subsection{Soil physico-chemical properties}

The soil depth varied from $50 \mathrm{~cm}$ to $>200 \mathrm{~cm}$ (Fig. 2; Appendices A2-A5). At the upslope positions, the depth to saprolite varied from 90 to $>140 \mathrm{~cm}$, depending on the location of the soil profile along the slope transect. Where the upslope profiles are located on the low-relief convexities $\left(<6^{\circ}\right.$ slope gradient), the soil depth is maximal. In the forested sites, soils are systematically deeper in the lower middle and 
toeslope positions compared to the shoulder positions. Under cropland, the soil depth in the steep slope ranges between 90 and $110 \mathrm{~cm}$, with slightly deeper colluvial soil in the toeslope position (CroS-Bot; $110 \mathrm{~cm}$ ) compared to the middle slope position (CroS-M, $90 \mathrm{~cm})$. The gentle slope under cropland (CroG) is characterised by deeper soil profiles than the steep slope (CroS), and the contact with the saprolite was not reached because of waterlogging.

The bulk density in forest soils ranges between 0.72 and $1.54 \mathrm{~g} \mathrm{~cm}^{-3}$ and in cropland soils between 1.03 and $1.49 \mathrm{~g} \mathrm{~cm}^{-3}$ (Appendix, Table A6). The lowest bulk density values $\left(0.72-1.02 \mathrm{~g} \mathrm{~cm}^{-3}\right)$ are observed in the soil profile developed at the upslope position of the forest steep slope (FoS-Top). This profile is characterised by the lowest $\mathrm{pH}$ values measured in forest soils, with a $\mathrm{pH}$ value of 4.67 to 4.73 compared to an average value of $5.16 \pm 0.29$ for forest soils (Appendix, Table A6). Also, it is the only soil profile with a constant cation exchange capacity (CEC) of $25 \pm 2 \mathrm{cmol}_{\mathrm{c}} \mathrm{kg}^{-1}$ (Appendix, Fig. A5) and constant Fed/Fet ratio of $0.66 \pm 1$ (Fig. 4) with depth. Therefore, we assume that the upslope soil profile in the forest steep slope (FoS-Top) is the most representative one for studying autochtonous soil development.

\subsection{Soil mineralogy}

The bedrock mineralogy is dominated by sanidine (K-feldspar, $\sim 45$ to $55 \%)$ and fine grained quartz $(\sim 38 \%)$. Other minerals such as cristobalite and clay minerals occur in minor proportions ( $<10 \%$, Fig. 3 ). The X-ray diffractograms show that all bulk soil samples have a mineral assemblage that is very similar to the bedrock samples from forest and cropland sites (Fig. 3), indicating that the mineralogy of the parent material is rather homogeneous over the study sites. The bulk soil samples' mineralogy (Table 1) consists of quartz (38-79\%), halloysite (7-26\%) and kaolinite (8-27\%). The toeslope position of the forest steep slope is particularly rich in quartz, and contains very low kaolinite contents (Table 1). Sanidine is present in all samples at least in trace amounts: it is low in forests and the cropland gentle slope (reliably quantifiable only in the topsoil of the toeslope soils, $6.5 \pm 0.7 \%$ ) while the highest amounts of sanidine were found in soils from cropland steep slope $(12 \pm 5 \%)$. Soils along the cropland steep slope are rather particular in clay mineralogy (Appendix, Fig. A4) with presence of smectite and absence of vermiculite in contrast to the forest and cropland gentle slope profiles. Hematite, goethite, gibbsite and cristobalite are observed in all sites (Table 1), and traces of illite are seen but could not be quantified (Appendix, Fig. A4).

\subsection{Soil weathering indices}

The four weathering indices $\left(\mathrm{Fe}_{\mathrm{d}} / \mathrm{Fe}_{\mathrm{t}}\right.$, clay content, CIA, and TRB) derived for the 14 soil profiles showed significant correlation among themselves. The Spearman correlation coefficients range between 0.55 and 0.98 (p-value $<0.05$ ), pointing to overall congruence in the dataset. This is also the case for the two weathering indices based on the base cation content (TRB, CIA), indicating that external cation input from fertilisers is not strongly altering the total cation content of the agricultural soil. Appendix A1 provides more information on the base cation input from fertilisers in the agricultural soils.

The ratio of iron oxides to total iron $\left(\mathrm{Fe}_{\mathrm{d}} / \mathrm{Fe}_{\mathrm{t}}\right)$ in the soils ranges

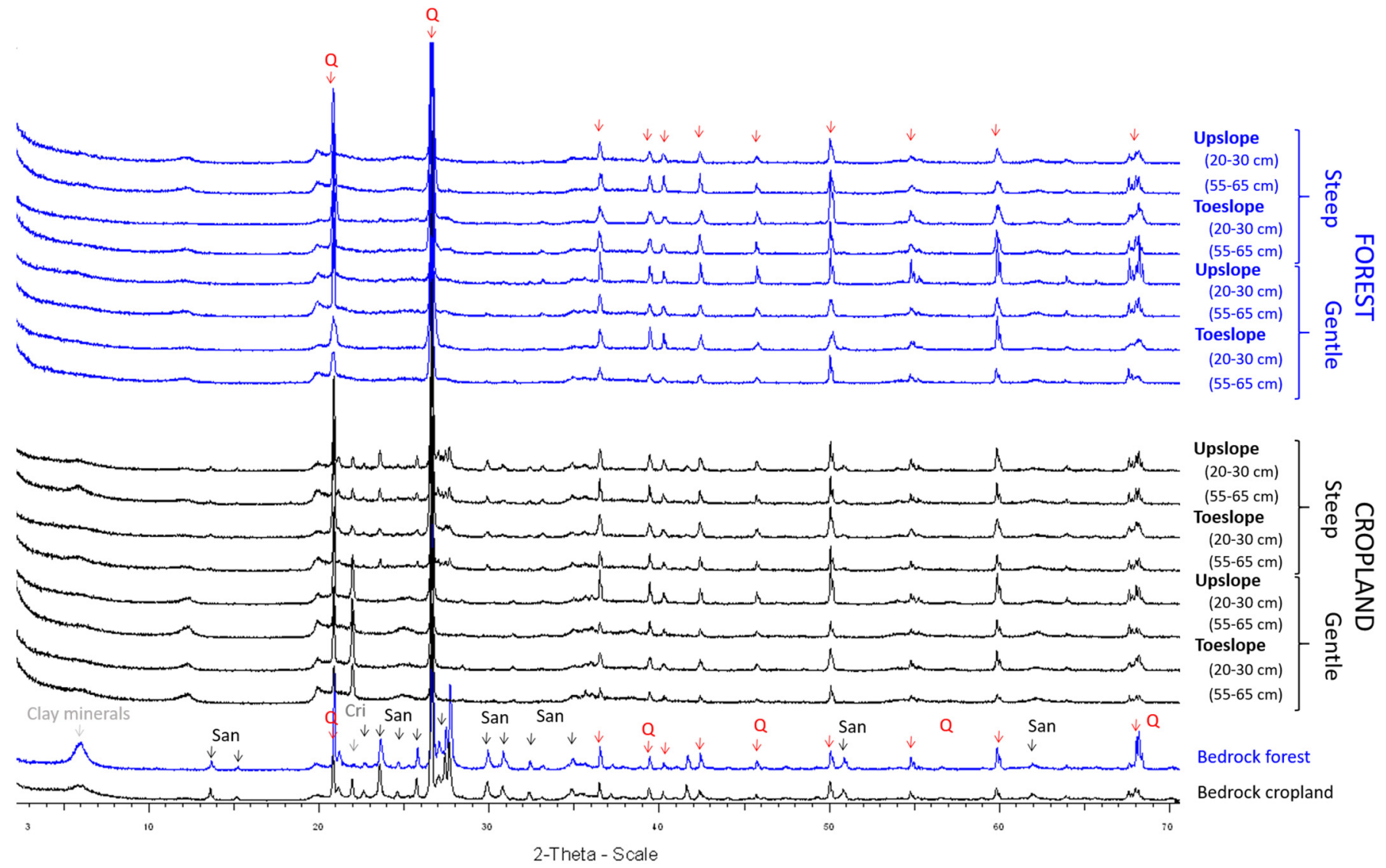

Fig. 3. Diffractograms of a subset of 16 bulk soil samples and 2 bedrock samples (measured on powder samples). The bedrock samples come from outcrops in the Ilopolis forest and Arvorezinha cropland catchment. The selected soil samples come from the soil profiles in the upslope and toeslope position of the forest steep, forest gentle, cropland steep and cropland gentle toposequences. Two bulk samples per soil profile were analysed with XRD: one sample from the $20-30 \mathrm{~cm}$ layer, and a second one from the $55-65 \mathrm{~cm}$ soil layer. The different peaks correspond to the main mineral phases present in the sample. $Q=$ quartz, San $=$ sanidine, Cri $=$ cristobalite, clay minerals $=$ smectite type $(2: 1)$. 
Table 1

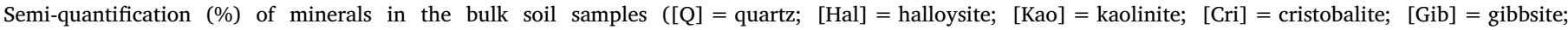

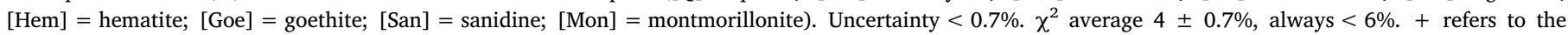
presence of the mineral $(<5 \%)$.

\begin{tabular}{|c|c|c|c|c|c|c|c|c|c|c|c|}
\hline Slope & Slope position & Sample depth $(\mathrm{cm})$ & $\mathrm{Q}$ & Hal & Kao & Cri & Gib & Hem & Goe & San & Mon \\
\hline \multirow[t]{4}{*}{ Forest steep (FoS) } & Top & $20-30$ & 54 & 26 & 12 & + & + & + & + & & \\
\hline & & $55-65$ & 66 & 15 & 13 & + & + & + & + & & \\
\hline & Bottom & $20-30$ & 79 & 7 & & & & + & + & 7 & \\
\hline & & $55-65$ & 63 & 16 & 15 & & + & & 5 & & \\
\hline \multirow[t]{3}{*}{ Forest gentle (FoG) } & Top & $20-30$ & 55 & 18 & 14 & + & & & 6 & + & \\
\hline & & $55-65$ & 55 & 25 & 16 & & & & + & + & \\
\hline & Upper middle & $20-30$ & 66 & 17 & 11 & & + & & + & + & \\
\hline \multirow[t]{4}{*}{ Cropland steep (CroS) } & Top & $20-30$ & 61 & 4 & 14 & + & & + & + & 15 & \\
\hline & & $55-65$ & 45 & 7 & 19 & + & + & + & + & 11 & 11 \\
\hline & Bottom & $20-30$ & 61 & 4 & 7 & + & + & + & 7 & 17 & \\
\hline & & $55-65$ & 52 & 5 & 18 & + & & 11 & 8 & 5 & \\
\hline \multirow[t]{3}{*}{ Cropland gentle (CroG) } & Top & $20-30$ & 60 & 19 & 8 & 4 & & 9 & & & \\
\hline & & $55-65$ & 38 & 20 & 19 & 6 & & 8 & 6 & + & \\
\hline & Bottom & $20-30$ & 58 & 10 & 11 & 8 & & + & + & 6 & \\
\hline
\end{tabular}

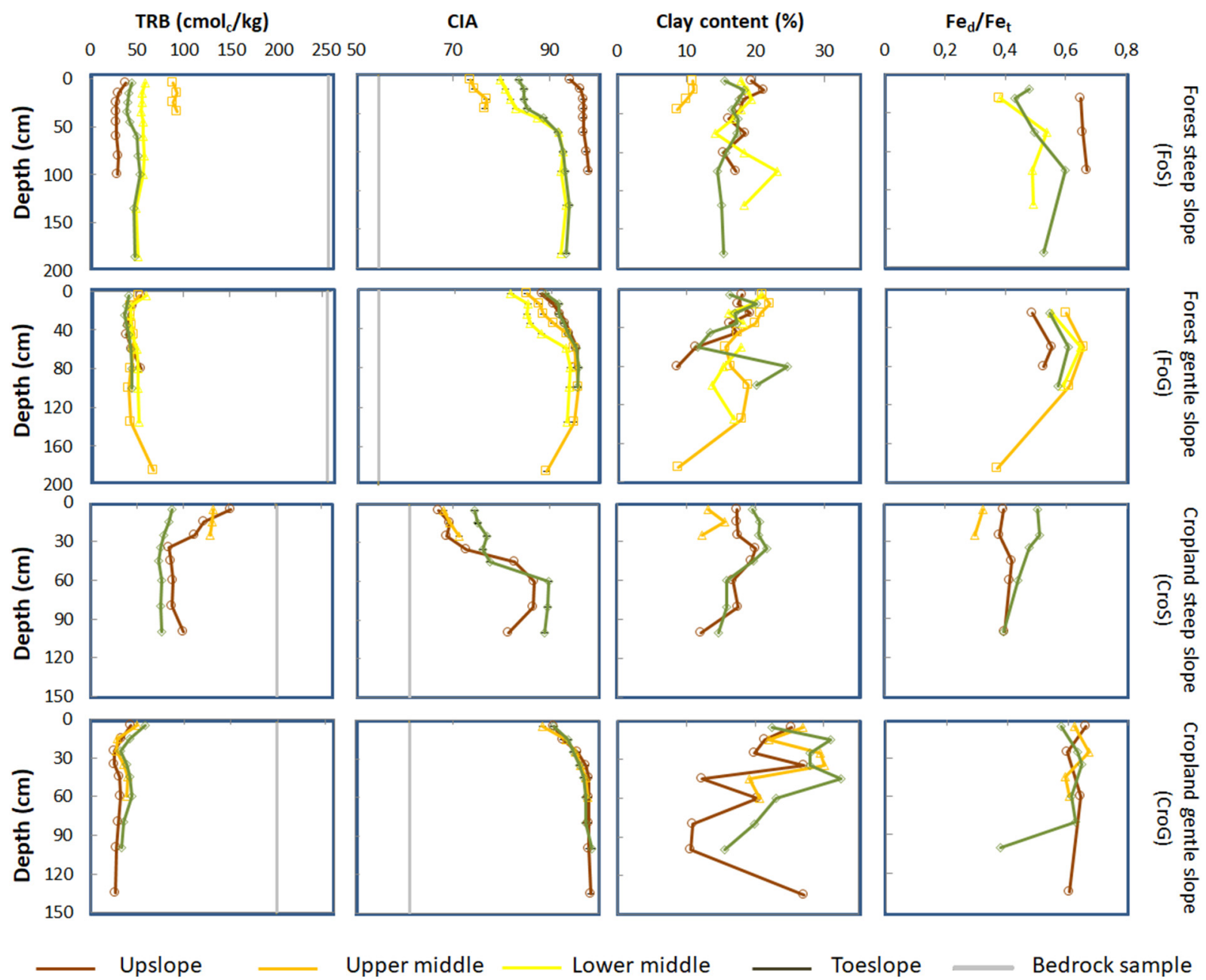

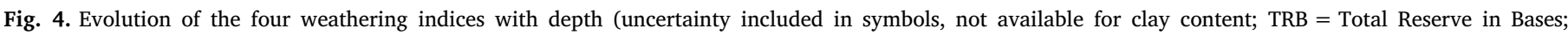

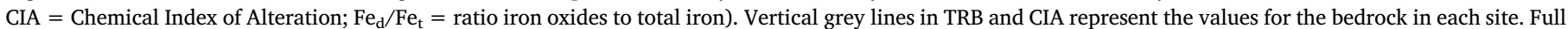
dataset is available in Appendix (Table A7).

from 0.3 to 0.67 (Fig. 4; Appendix, Table A7). In gentle slopes, the $\mathrm{Fe}_{\mathrm{d}}$ / $\mathrm{Fe}_{\mathrm{t}}$ values are similar in forest and cropland, and do not vary as a function of the slope position (FoG, $0.56 \pm 0.08$; CroG, $0.60 \pm 0.07$ ). In steep slopes, the $\mathrm{Fe}_{\mathrm{d}} / \mathrm{Fe}_{\mathrm{t}}$ values vary as a function of the slope position: in forest, the highest $\mathrm{Fe}_{\mathrm{d}} / \mathrm{Fe}_{\mathrm{t}}$ value is found at the top position (FoS-Top, $0.66 \pm 0.01$, highest value among all profiles), and the lowest value is found in the upper middle position (FoS-UM, 0.38); in cropland, the middle position is characterised by the lowest $\mathrm{Fe}_{\mathrm{d}} / \mathrm{Fe}_{\mathrm{t}}$ value of all profiles (CroS-M, $0.31 \pm 0.02$; Fig. 5). The clay content in the soils ranges from 10 to $32 \%$ (Fig. 4; Appendix, Table A7), and is similar in forest (FoS: $17 \pm 3 \%$, FoG: $17 \pm 4 \%$ ) and in cropland steep slope (CroS, $17 \pm 3 \%)$. The highest clay content is observed in 


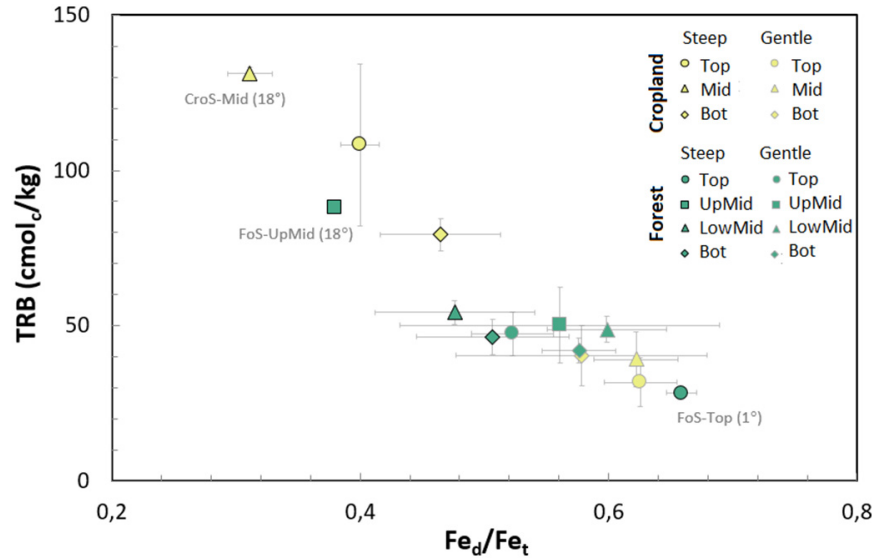

Fig. 5. Total Reserve in Bases (TRB) as a function of the ratio of iron oxides to total iron $\left(\mathrm{Fe}_{\mathrm{d}} / \mathrm{Fe}_{\mathrm{t}}\right)$ in soils. The soils with high TRB and low $\mathrm{Fe}_{\mathrm{d}} / \mathrm{Fe}_{\mathrm{t}}$ display low weathering degree, and the soils with low TRB and high $\mathrm{Fe}_{\mathrm{d}} / \mathrm{Fe}_{\mathrm{t}}$ display high weathering degree. The soil profiles along the gentle toposequence cover a very narrow range of TRB vs. $\mathrm{Fe}_{\mathrm{d}} / \mathrm{Fe}_{\mathrm{t}}$ values, in contrast to the profiles along the steep toposequences in forest and cropland.

cropland gentle slopes (32\%) but the average for the slope (CroG, $23 \pm 6 \%$ ) is indistinguishable from the average for the other slopes. The lowest clay content is found in the upper middle position in forest steep slope (FoS-UM, $10 \pm 1 \%$ ).

The last two weathering indices, CIA and TRB, were also derived for the bedrock samples. In the bedrock, the TRB value varies between 200 and $250 \mathrm{cmol}_{\mathrm{c}} \mathrm{kg}^{-1}$ and the Chemical Index of Alteration (CIA) varies between 54 and 61. All soil samples display lower TRB values and higher CIA values than those of the bedrock (Fig. 4). In soils, the TRB values range from 25 to $151 \mathrm{cmol}_{\mathrm{c}} \mathrm{kg}^{-1}$ (Fig. 4; Appendix, Table A7). In gentle slopes, both in forest and cropland, the TRB values are similar and do not vary as a function of the slope position (FoG, $46 \pm 7 \mathrm{cmol}_{\mathrm{c}}$ $\mathrm{kg}^{-1}$; CroG, $36 \pm 8 \mathrm{cmol}_{\mathrm{c}} \mathrm{kg}^{-1}$ ). In contrast, in steep slopes, the TRB values are lower in forest (FoS, $50 \pm 18 \mathrm{cmol}_{\mathrm{c}} \mathrm{kg}^{-1}$ ) compared to cropland (CroS, $98 \pm 24 \mathrm{cmol}_{\mathrm{c}} \mathrm{kg}^{-1}$, the highest average TRB value of all slopes). Moreover, the TRB values in soils along the steep slopes vary as a function of the slope position (Fig. 5). In forest, the TRB is the lowest in the top position (FoS-Top, $30 \pm 3 \mathrm{cmol}_{\mathrm{c}} \mathrm{kg}^{-1}$ ) and the highest in the upper middle position (FoS-UM, $90 \pm 2 \mathrm{cmol}_{\mathrm{c} \mathrm{kg}}{ }^{-1}$ ), while in cropland, the highest TRB value is also observed in the middle slope position (CroS-M, $131 \mathrm{cmol}_{\mathrm{c}} \mathrm{kg}^{-1}$; Fig. 4). The CIA values in soils range from 67 to 98, and display a similar behaviour with slope position and slope gradient as the TRB values (Fig. 4; Appendix, Table A7) although in the opposite direction (given that TRB decreases and CIA increases with increasing weathering).

The variation of the four weathering indices with depth is strongest for the steep toposequence in cropland, intermediate for the forest steep and cropland gentle slopes, and lowest for the forest gentle slope (Fig. 4). Soils along the gentle toposequences in forest and cropland are strongly depleted in base cations at depth, as shown by the vertical distributions of the TRB values in the (30-90) $\mathrm{cm}$ depth range. The topsoil material (0-30 cm depth range) is less depleted in base cations and has lower weathering extent than the deeper (30-90 cm depth) soil material. As this enrichment in base cations in the topsoil is observed for forest and cropland sites, it cannot be attributed to the anthropogenic fertilisation alone.

\section{Discussion}

\subsection{Redistribution of pedogenic material on forested slopes}

The upslope soil profile of the forested steep slope (FoS-Top) is the only pit in forests that is situated on the edge of the plateau with a slope
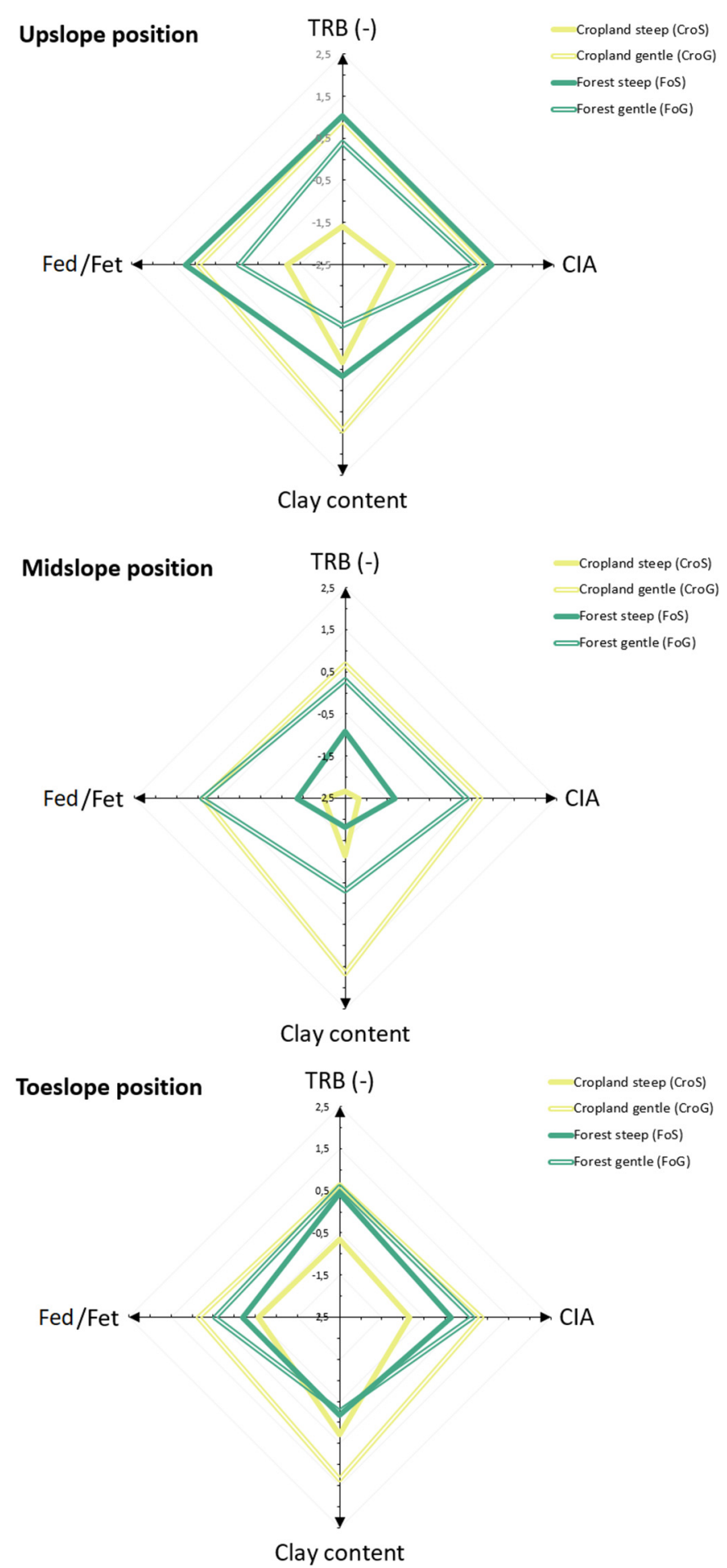

Fig. 6. Spider diagrams showing the relative weathering extent of the soil profiles along the toposequences. The weathering degree is based on four weathering indices: Total Reserve in Bases (TRB); Chemical Index of Alteration (CIA); clay content, and ratio of iron oxides to total iron $\left(\mathrm{Fe}_{\mathrm{d}} / \mathrm{Fe}_{\mathrm{t}}\right)$. To facilitate comparison between sites, the values for the four weathering indices were standardised, and plotted as z-scores. The TRB values were inversed, so that the highest z-scores correspond to the maximum weathering extent measured in the profiles.

gradient of $1^{\circ}$ (Fig. 1). The ${ }^{10}$ Be-derived erosion rates of this hilltop convexity have been established at $5.0 \pm 0.5 \mathrm{~mm} \mathrm{kyr}^{-1}$ (Schoonejans et al., 2017). This soil profile has the highest soil weathering degree, as shown by its low TRB, high CIA and high $\mathrm{Fe}_{\mathrm{d}} / \mathrm{Fe}_{\mathrm{t}}$ values relative to the 
other soil profiles (Figs. 5, 6). Its soil mineralogy is also indicative for a high degree of soil weathering: the presence of kaolinite-type minerals and the low content in primary minerals such as sanidine has been associated with highly weathered forest soils developed on rhyodacitic parent material in Rio Grande do Sul (Dümig et al., 2008; Caner et al., 2014). However, the clay content of the upslope soils is low (15-21\%), which can be explained by the accumulation of quartz in soil material due to its inherently high contents in the parent material.

Steeper valley flanks enclose the low-relief hilltop convexities (here only sampled at FoS-Top, as FoS-G corresponds to the transition to the upper middle position, Fig. 1). Soil truncation of the upper middle soil profiles (clearly observed at FoS-UM, Fig. 2) provides evidence of enhanced lateral soil fluxes at the mid slope position where the slope gradient equals $12^{\circ}$ to $18^{\circ}$. The soil pattern and slope morphology point to local topographic disequilibrium, with progressive steepening of the hillslope from the upper convexities to the mid slope positions. Enhanced erosive processes on slopes removing topsoil material can drive soil rejuvenation (Chadwick and Asner, 2016). Fig. 6 illustrates that the lowest values of soil weathering degree occur in the upper middle position of the steep forest slope, illustrative for the exposure of less weathered subsurface horizons after soil truncation.

Along the valley flanks, the soil depth augments with increasing distance from the crest. Fig. 2 illustrates the increase in soil depth from the upper middle to lower middle and toeslope positions for the gentle and steep toposequences. This observation is consistent with lateral redistribution of soil constituents via erosion processes. Geomorphic processes redistribute pedogenic material downslope with accumulation of soil material in the basal concavities where the slope gradient decreases (e.g., Hall, 1983; Vitousek et al., 2003; Chadwick and Asner, 2016). The toeslope positions correspond to the concave downslope parts of the toposequences, where soil material accumulates and soil depths increase up to $>200 \mathrm{~cm}$ (Fig. 2). The downslope increase in meteoric ${ }^{10} \mathrm{Be}$ inventories (Schoonejans et al., 2017) and biogenic Si pools (Unzué-Belmonte et al., 2017) are indicative for soil accumulation in the toeslope positions. Soil redistribution and mixing result in spatial patterns in weathering along the valley flanks of the steep toposequence: the downslope sites (sampled at FoS-LM and FoS-Bot) have higher weathering intensities than the upper midslope positions (FoS$\mathrm{UM})$, here shown by lower TRB values, higher CIA values, and higher clay content in FoS-LM and FoS-Bot compared to FoS-UM (Fig. 3). Also, the soil mineralogy (Table 1) indicates that the topsoil material of the FoS-Bot profile (at $20-30 \mathrm{~cm}$ ) is characterised by the presence of sanidine (7\%) and the highest quartz content of all samples (79\%).

Compared to the steep toposequence, there are fewer differences in soil constituents, soil physico-chemical properties, and soil weathering degree as a function of topographic position on the gentle toposequence (Figs. 4, 6; Appendix, Table A7). It is likely that the redistribution of pedogenic material along the gentle toposequence is not sufficient to result in a clear spatial variation in soil constituents and soil properties along slope (Fig. 5).

\subsection{Redistribution of pedogenic material on agricultural slopes}

The average erosion rate of the eroding portion of the cropland catchment has been estimated at $42 \mathrm{Mg} \mathrm{ha}^{-1} \mathrm{yr}^{-1}$ for the past 55 years by Minella et al. (2014). The average ${ }^{137} \mathrm{Cs}$-derived erosion rate includes sites with different slope angles and land occupation. Taking into account the average soil bulk density in our soils (Appendix, Table A7), this represents an average loss of soil of $\sim 30 \mathrm{~cm}$ over the past 100 years of cultivation. Accelerated soil erosion following forest conversion leads to soil truncation and rejuvenation of the soil surface by exposure of subsurface horizons with distinct mineralogy and physico-chemical characteristics compared to the soil surface prior to erosion. All CroS soil profiles are characterised by a high TRB, low CIA, low clay content and low $\mathrm{Fe}_{\mathrm{d}} / \mathrm{Fe}_{\mathrm{t}}$ values (Fig. 5), pointing to a relatively low extent of chemical weathering. The CroS soil profiles show TRB and CIA values that differ between the upper $30 \mathrm{~cm}$ and deeper soil horizons, while $\mathrm{Fe}_{\mathrm{d}} / \mathrm{Fe}_{\mathrm{t}}$ values and clay content do not vary with depth (Fig. 3). Fertiliser input may partly explain the anomalously high TRB and low CIA values at the surface, because of artificial increase of the cation content by anthropogenic fertilisation of the plough layer (Appendix A1). Other weathering indices, not depending on the cation content, such as the $\mathrm{Fe}_{\mathrm{d}} / \mathrm{Fe}_{\mathrm{t}}$ ratio (Fig. 3) do not show systematic variation in soil weathering degree with depth. Along the steep toposequence, all three soil profiles are sampled on the steeper valley flanks. High anthropogenic erosion rates of $\sim 3 \mathrm{~mm} \mathrm{yr}^{-1}$ (Minella et al., 2014) resulted in truncated soil profiles (CroS-M, Cro-Bot) and soil rejuvenation. The soil weathering degree is lowest at the steep $\left(18^{\circ}\right)$ mid slope position, and increases strongly downslope as the result of soil redistribution and mixing.

In contrast to the steep toposequence, the gentle slope (CroG) does not show systematic variation in soil physico-chemical properties along the slope (Fig. 6). There exist clear differences in the soil mineralogy between the steep and gentle toposequence: the steep slope is characterised by a higher presence of the primary mineral sanidine and a lower abundance of halloysite than the cropland gentle slope, and by the presence of smectite type minerals $(2,1)$ that are absent from the cropland gentle slope (Table 1). Smectite is only observed in the upslope position of the steep toposequence (CroS-Top), where the presence of primary minerals is highest and the TRB, CIA and $\mathrm{Fe}_{\mathrm{d}} / \mathrm{Fe}_{\mathrm{t}}$ are indicative of a low degree of weathering (Fig. 5). The coexistence of kaolinite and 2:1 minerals in this superhumid subtropical area of Brazil has been also reported elsewhere (Bortoluzzi et al., 2008, 2012; Inda et al., 2010; Caner et al., 2014).

\subsection{Geomorphology and land use influencing erosion-driven soil rejuvenation}

Our data show evidence of strong spatial variation in soil physicochemical and mineralogical properties. The convex hilltops are characterised by the highest degree of soil chemical weathering, with depletion of base cations at depth and presence of kaolinite-type clay minerals. The transition from the slowly eroding hilltops to the dissected valley flanks corresponds to a topographic disequilibrium, with a nonlinear change in soil weathering extent. Our data show that the largest variation in weathering degree along slope is observed in the steep toposequences, where the geomorphic process rates are highest and lateral movement of topsoil material leads to erosion of depleted topsoil and exposure of less weathered subsurface material (Fig. 7). This confirms the role of geomorphic processes in rejuvenating soils, as suggested by Chadwick and Asner (2016). In contrast to the steep slopes, we do not observe clear spatial gradients in weathering degree along the gentle toposequences in forests and cropland (Figs. 6, 7). On the gentle slopes, all soil profiles are highly depleted in base cations and the four weathering indices (TRB, CIA, clay content and $\mathrm{Fe}_{\mathrm{d}} / \mathrm{Fe}_{\mathrm{t}}$, Fig. 5) are indicative for a more advanced weathering extent of the soil mantle along the toposequence relative to the steep slopes. It is possible that the soil mantle is already too weathered to experience any subsequent change in weathering degree downslope or that the increase in soil particle residence time downslope is short compared to its overall exhumation time in the soil mantle.

Land use change, such as the conversion of forest to cropland, accelerates soil erosion rates (Pimentel, 2006; Vanacker et al., 2007). Minella et al. (2014) demonstrated that the conversion of forest to cropland accelerated soil erosion rates in the Arvorezinha area. Erosiondriven soil rejuvenation is slope-dependent, and particularly enhanced on the steep mid slope part of the cropland toposequence. Among all soil profiles investigated (including forest slopes), the cropland steep slope (with slope angle of $18 \pm 4^{\circ}$; Fig. 2) presents the lowest soil weathering degree (Figs. 5 and 6), likely as a result of incorporation of less weathered subsurface material into the soil matrix following soil truncation by accelerated soil erosion. Bortoluzzi et al. (2012) reported 


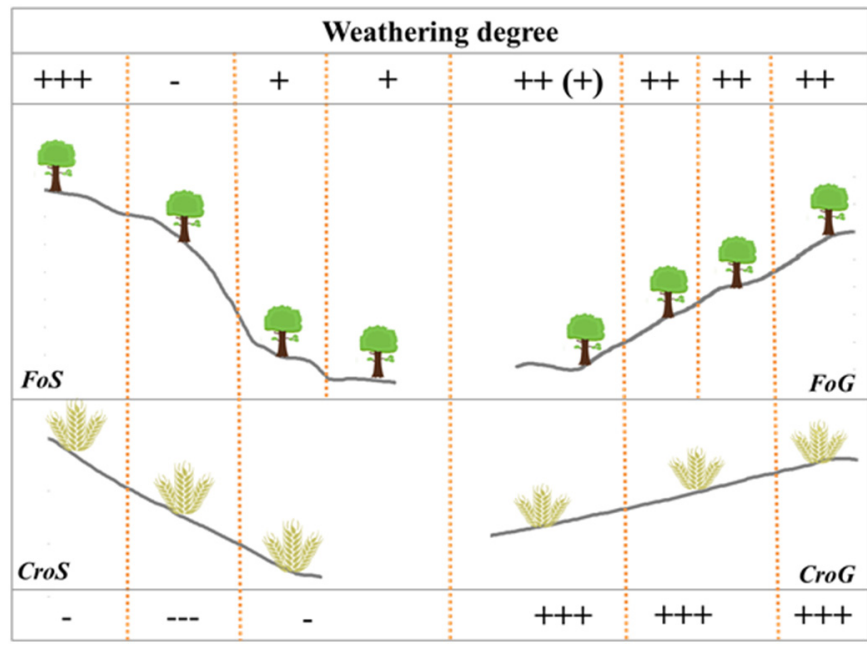

Fig. 7. Conceptual scheme showing the weathering degree of each profile relative to the weathering degree of the reference profile in the top position under steep slope. The profile with the lowest weathering degree (middle position on cropland steep slope, CroS-M) has been assigned the code - and the profiles with the highest weathering degree (all cropland gentle slope profiles, CroG, and forest steep top position, FoS-Top) have been assigned the code +++ . The rest of the profiles are classified in between relative to the two end-members. Degree of weathering: $-<-<+<++<+++$.

similar changes in soil chemistry $\left(\mathrm{Fe}_{\mathrm{d}}\right)$ when analysing conversion of native forest to vineyards in South Brazil, and reported a decrease of $\mathrm{Fe}_{\mathrm{d}}$ from 359 to $391 \mathrm{mg} \mathrm{kg}^{-1}$ under forests to $243-290 \mathrm{mg} \mathrm{kg}^{-1}$ under vineyard. In our soil profiles, the mineralogical assemblages with higher abundance of primary minerals and presence of smectite in the steep cropland soils further support this statement.

Our dataset provides preliminary insights in the dynamic interplay between soil weathering degree and natural versus anthropogenic erosion-driven soil rejuvenation. In combination with information derived from cosmogenic radionuclides (Schoonejans et al., 2017), our dataset enables evaluation and calibration of numerical models (Campforts et al., 2016) potentially allowing spatial and temporal extrapolation of the relation between land use and temporal dynamics of soil evolution along hillslopes. Although the conversion of forest to cropland can directly influence soil weathering processes through changes in e.g. nutrient uptake, soil temperature and hydrology (e.g., Heitkamp et al., 2014), our data suggest that indirect effects of land use change through accelerated soil erosion and soil rejuvenation can lead to strong variation in soil physico-chemical and mineralogical properties along slopes.

\section{Conclusions}

The present study used a comparative approach to assess the impact of geomorphology and land use on spatial variation in chemical weathering degree along hillslopes. Lateral soil fluxes along slope can introduce spatial gradients in soil physico-chemical and mineralogical properties, resulting from translocation of weathered topsoil particles downslope. Our data show that the differentiation in chemical weathering degree is strongly slope-dependent, with none to limited differentiation along the two gentle hillslopes (with average slope gradient $<9^{\circ}$ ) and high spatial differentiation along steep hillslopes (with average slope gradient $>13^{\circ}$ ). Erosion-driven differentiation in weathering degree is observed for the steep toposequences in forests and cropland. Accelerated erosion by conversion of forests to cropland further enhances lateral soil fluxes, and redistribution of weathered topsoil material along slope. Compared to the forest steep slope (FoS), the cropland steep slope (CroS) shows evidence of stronger rejuvenation of weathered-derived soil nutrients after soil truncation and mixing of less weathered subsurface material into the soil mantle. Further investigations are needed to assess whether this subset of four toposequences is representative for constraining spatio-temporal patterns in soil weathering at the catchment scale.

\section{Acknowledgements}

We want to thank the staff of the Soils Department of Universidade Federal de Santa Maria during the preparation and realisation of the sampling campaign and for bulk density measurements (A. Schlesner, C. Barros, R. Ramon, L. Ávila). We thank A. Iserentant, C. Givron and M. Bravin for help in sample preparation and geochemical characterisation. The manuscript benefited from discussions with D. Houben and G. Govers. We thank the editor Markus Egli, Gilles Brocard and three anonymous reviewers for their constructive comments to improve the manuscript. Y.A.M., J.S., J.R., and B.C. are funded by the Belgian Science Policy Office (BELSPO) in the framework of the Inter University Attraction Pole project (P7/24): SOGLO - The soil system under global change. S.O. is funded by the "Fonds National de la Recherche Scientifique" (FNRS, Belgium, FC69480). B.C. is currently funded by a postdoctoral grant from the Research Foundation Flanders (FWO).

\section{Appendix A. Supplementary data}

Supplementary data to this article can be found online at https:// doi.org/10.1016/j.catena.2019.03.024.

\section{References}

Ameijeiras-Mariño, Y., Opfergelt, S., Schoonejans, J., Vanacker, V., Sonnet, P., De Jong, J., Delmelle, P., 2017. Impact of low denudation rates on soil chemical weathering intensity: a multiproxy approach. Chem. Geol. 456, 72-84.

Ameijeiras-Mariño, Y., Opfergelt, S., Derry, L.A., Robinet, J., Govers, G., Minella, J.P.G., Delmelle, P., 2018. Ge/Si ratios point to increased contribution from deeper mineral weathering to streams after forest conversion to cropland. Appl. Geochem. 96, 24-34.

Baker, W.E., 1973. The role of humic acids from Tasmanian podzolic soils in mineral degradation and metal mobilization. Geochim. Cosmochim. Acta 37, 269-281.

Barak, P., Jobe, B.O., Kreuger, A.R., Peterson, L.A., Laird, D.A., 1997. Effects of long-term acidification due to nitrogen fertilizer inputs in Wisconsin. Plant Soil 197, 61-69.

Bellieni, G., Comin-Chiaramonti, P., Marques, L., Melfi, A., Nardy, A., Papatrechas, C., Piccirillo, E., Roisenberg, A., Stolfa, D., 1986. Petrogenetic aspects of acid and basaltic lavas from the Paraná plateau (Brazil): geological, mineralogical and petrochemical relationships. J. Petrol. 27 (4), 915-944.

Beuselinck, L., Govers, G., Poesen, J., Degraer, G., Froyen, L., 1998. Grain-size analysis by laser diffractometry: comparison with the sieve-pipette method. Catena 32, 193-208.

Bortoluzzi, E.C., Velde, B., Pernes, M., Dur, J.C., Tessier, D., 2008. Vermiculite, with hydroxyaluminium interlayer, and kaolinite formation in a subtropical sandy soil from South Brazil. Clay Miner. 43, 185-193.

Bortoluzzi, E.C., Moterle, D.F., dos Santos Rheinheimer, D., Casali, C.A., Melo, G.W., Brunetto, G., 2012. Mineralogical changes caused by grape production in a regosol from subtropical Brazilian climate. J. Soils Sediments 12, 854-862.

Bosch, J.M., Hewlett, J.D., 1982. A review of catchment experiments to determine the effect of vegetation changes on water yield and evapotranspiration. J. Hydrol. 55, $3-23$.

Burke, B.C., Heimsath, A.M., White, A.F., 2007. Coupling chemical weathering with soil production across soil-mantled landscapes. Earth Surf. Process. Landforms 32, 853-873.

Campforts, B., Vanacker, V., Vanderborght, J., Baken, S., Smolders, E., Govers, G., 2016. Simulating the mobility of meteoric $10 \mathrm{Be}$ in the landscape through a coupled soil hillslope model (Be2D). Earth Planet. Sc. Lett. 439, 143-157.

Caner, L., Radtke, L.M., Vignol-Lelarge, M.L., Inda, A.V., Bortoluzzi, E.C., Mexias, A.S., 2014. Basalt and rhyo-dacite weathering and soil clay formation under subtropical climate in southern Brazil. Geoderma 235-236, 100-112.

Carson, M.A., Kirkby, M.J., 1972. Hillslope Form and Process. Cambridge Geographical Studies No. 3. Cambridge University Press, Cambridge.

Cerdan, O., Govers, G., Le Bissonnais, Y., Van Oost, K., Poesen, J., Saby, N., Gobin, A., Vacca, A., Quinton, J., Auerswald, K., Klik, A., Kwaad, F.J.P., Raclot, D., Ionita, I., Rejman, J., Rousseva, S., Muxart, T., Roxo, M.J., Dostal, T., 2010. Rates and spatial variations of soil erosion in Europe: a study based on erosion plot data. Geomorphology 122 (1-2), 167-177.

Chadwick, K.D., Asner, G.P., 2016. Tropical soil nutrient distributions determined by biotic and hillslope processes. Biogeochemistry 127, 273-289.

Chadwick, O.A., Gavenda, R.T., Kelly, E.F., Ziegler, K., Olson, C.G., Crawford Elliott, W., Hendricks, D.M., 2003. The impact of climate on the biogeochemical functioning of volcanic soils. Chem. Geol. 202, 195-223.

Chao, T.T., Sanzolone, R.F., 1992. Decomposition techniques. J. Geochem. Explor. 44 65-106. 
Chin, A., Fu, R., Harbor, J., Taylor, M.P., Vanacker, V., 2013. Anthropocene: human interactions with earth systems. Anthropocene 1, 1-2.

Cornu, S., Montagne, D., Hubert, F., Barré, P., Caner, L., 2012. Evidence of short-term clay evolution in soils under human impact. Compt. Rendus Geosci. 344, 747-757.

Dixon, J.L., Chadwick, O.A., Vitousek, P.M., 2016. Climate-driven thresholds for chemical weathering in postglacial soils of New Zealand. J. Geophys. Res. Earth Surf. 121, 1619-1634.

Drever, J.I., 1994. The effect of land plants on weathering rates of silicate minerals. Geochim. Cosmochim. Acta 58, 2325-2332.

Dümig, A., Schad, P., Kohok, M., Beyerlein, P., Schwimmer, W., Kögel-Knabner, I., 2008. A mosaic of nonallophanic andosols, Umbrisols and Cambisols on rhyodacite in the southern Brazilian highlands. Geoderma 145, 158-173.

Eshel, G., Levy, G.J., Mingelgrin, U., Singer, M.J., 2004. Critical evaluation of the use of laser diffraction for particle-size distribution analysis. Soil Sci. Soc. Am. J. 68, 736-743. https://doi.org/10.2136/sssaj2004.7360.

Fedo, C.M., Nesbitt, H.W., Young, G.M., 1995. Unraveling the effects of potassium metasomatism in sedimentary rocks and paleosols, with implications for paleoweathering conditions and provenance. Geology 23, 921-924.

Fisher, P., Aumann, C., Chia, K., O'Halloran, N., Chandra, S., 2017. Adequacy of laser diffraction for soil particle size analysis. PLoS One 12 (5), e0176510.

Foley, J.A., 2011. Can we feed the world and sustain the planet? Sci. Am. 305, 60-65.

Foley, J.A., Costa, M.H., Delire, C., Ramankutty, N., Snyder, P., 2003. Green surprise? How terrestrial ecosystems could affect Earth's climate. Front. Ecol. Environ. 1, 38-44.

Foley, J.A., Defries, R., Asner, G.P., Barford, C., Bonan, G., Carpenter, S.R., Chapin, F.S., Coe, M.T., Daily, G.C., Gibbs, H.K., Helkowski, J.H., Holloway, T., Howard, E.A., Kucharik, C.J., Monfreda, C., Patz, J.A., Prentice, I.C., Ramankutty, N., Snyder, P.K., 2005. Global consequences of land use. Science 309, 570-574.

Food and Agriculture Organization, FAO, 2006. Guidelines for soil description, 4th ed. (Rome).

Godfray, H.C.J., Beddington, J.R., Crute, I.R., Haddad, L., Lawrence, D., Muir, J.F., Pretty, J., Robinson, S., Thomas, S.M., Toulmin, C., 2010. Food security: the challenge of feeding 9 billion people. Science 327, 812-818.

Govers, G., Quine, T.A., Desmet, P.J.J., Walling, D.E., 1996. The relative contribution of soil tillage and overland flow erosion to soil redistribution on agricultural land. Earth Surf. Process. Landforms 21, 929-946.

Hall, G., 1983. Pedology and geomorphology. In: Wilding, L.P., Smeck, N.E., Hall, G.F. (Eds.), Pedogenesis and Soil Taxonomy. I. Concepts and Interactions. Elsevier, Amsterdam, pp. 117-140.

Heitkamp, F., Sylvester, S.P., Kessler, M., Mitsy, D.P.V., Sylvester, M.D.P.V., Hermann, F.J., 2014. Inaccessible Andean sites reveal human-induced weathering in grazed soils. Prog. Phys. Geogr. 1-26.

Herbillon, A.J., 1986. Chemical estimation of weatherable minerals present in the diagnostic horizons of low activity clay soils. In Proc. 8th Intern. Soil Classif. Workshop: Classification, Characterization and Utilization of Oxisols (eds. Beinroth, F.H., Camargo, M.N. and Eswaran). EMBRAPA, Rio de Janeiro, 39-48.

Hewawasam, T., von Blanckenburg, F., Bouchez, J., Dixon, J.L., Schuessler, J.A., Maekeler, R., 2013. Slow advance of the weathering front during deep, supply-limited saprolite formation in the tropical Highlands of Sri Lanka. Geochim. Cosmochim. Acta 118, 202-230.

Hooke, R.L., 2000. On the history of humans as geomorphic agents. Geology 28, 843-846.

IBGE, 2016. MAPA - GEOLOGIA (WebsService). Insituto Brasileiro de Geografia e Estatística, Rio de Janeiro.

Inda, A.V., Torrent, J., Barrón, V., Bayer, C., 2010. Aluminum hydroxy-interlayeredminerals and chemical properties of a subtropical Brazilian oxisol under notillage and conventional tillage. R. Bras. Ci. Solo 34, 33-41.

IUSS Working Group WRB, 2007. World Reference Base for Soil Resources 2006, First Update 2007. World Soil Resources Reports 103. FAO, Rome.

James, L.A., 2013. Legacy sediment: definitions and processes of episodically produced anthropogenic sediment. Anthropocene 2, 16-26.

Khormali, F., Ajamai, M., Ayoubi, S., Srinivasarao, C., Wani, S.P., 2009. Role of deforestation and hillslope position on soil quality attributes of loess-derived soils in Golestan province, Iran. Agric. Ecosyst. Environ. 134 (3-4), 178-189.

Klug, H.P., Alexander, L.E., 1954. X-ray Diffraction Procedures. Wiley, New York (695 p).

Lopes, F., 2006. Utilização do modelo Century para avaliar a dinâmica do carbono do solo em uma pequena bacia hidrográfica rural. Master Dissertation. Universidade Federal do Rio Grande do Sul, Porto Alegre.

Lucas, Y., 2001. The role of plant in controlling rates and products of weathering: importance of biological pumping. Annual Review of Earth and Planet. Sci. 29, 135-163.

Matocha, C.J., Grove, J.H., Karathanasis, T.D., Vandiviere, M., 2016. Changes in soil mineralogy due to nitrogen fertilization in an agroecosystem. Geoderma 263, 176-184.

McGahan, D.G., Southard, R.J., Zasoski, R.J., 2014. Rhizosphere effects on soil solution composition and mineral stability. Geoderma 226-227, 340-347.

Mehra, O.P., Jackson, M.L., 1960. Iron oxide removal from soils and clays by a dithionitecitrate system buffered with sodium bicarbonate. In: Proc. 7th Natl. Conf. Clays Clay Minerals, pp. 317-327 Washington.

Merten, G.H., Minella, J.P.G., 2006. Impact on sediment yield caused by intensification of tobacco production in a catchment in Southern Brazil. In: Walling, D.E., Horowitz, A.J. (Eds.), Sediment Budgets 2, IAHS Publ. 291. IAHS Press, Wallingford, UK, pp. 239-244.

Minella, J.P.G., 2003. Identificação de fontes de produção de sedimentos em uma pequena bacia rural (Identification of sediment sources in a small rural drainage basin). Dissertacão de Mestrado - Programa de Pós-Graduação em Recursos Hídricos e Saneamento Ambiental. Instituto de Pesquisas Hidráulicas. Universidade Federal do
Rio Grande do Sul, pp. 89.

Minella, J.P.G., Walling, D.E., Merten, G.H., 2008. Combining traditional monitoring and sediment source tracing techniques to assess the impact of improved land management on catchment sediment yields. J. Hydrol. 348, 546-563.

Minella, J.P.G., Merten, G.H., Walling, D.E., Reichert, J.M., 2009. Changing sediment yield as an indicator of improved soil management practices in southern Brazil. Catena 79, 228-236.

Minella, J.P.G., Walling, D.E., Merten, G.H., 2014. Establishing a sediment budget for a small agricultural catchment in southern Brazil, to support the development of effective sediment management strategies. J. Hydrol. 519, 2189-2201.

Molina, A., Vanacker, V., Brisson, E., Mora, D., Balthazar, V., 2015. Multidecadal change in streamflow associated with anthropogenic disturbances in the tropical Andes. Hydrol. Earth Syst. Sci. 19, 4201-4213.

Molina, A., Vanacker, V., Corre, M.D., Veldkamp, E., 2019. Patterns in soil chemical weathering related to topographic gradients and vegetation structure in a high Andean tropical ecosystem. Journal of Geophysical Research: Earth Surface 124 (2018JF004856).

Montanheiro, T.J., Yamamoto, J.K., Kihara, Y., 2004. Serra Geral Formation-São Paulo State, Brazil: a potential source for natural pozzolans. Mater. Lett. 58 (6), 876-881.

Montgomery, D.R., 2007. Soil erosion and agricultural sustainability. P. Natl. Acad. Sci. USA 104, 13268-13272.

Moore, D.M., Reynolds, R.C., 1997. X-ray Diffraction and the Identification and Analysis of Clay Minerals, 2nd ed. vol. 378 Oxford University Press, New York.

Morellato, L.P.C., Haddad, C.F.B., 2000. Introduction: the Brazilian Atlantic Forest. Biotropica 32 (4b), 786-792.

Moterle, D.F., Kaminski, J., dos Santos Rheinheimer, D., Caner, L., Bortoluzzi, E.C., 2016. Impact of potassium fertilization and potassium uptake by plants on soil clay mineral assemblage in South Brazil. Plant Soil 406, 157-172.

Mudd, S.M., Furbish, D.J., 2006. Using chemical tracers in hillslope soils to estimate the importance of chemical denudation under conditions of downslope sediment transport. J. Geophys. Res. 111 (F2).

Nesbitt, H.W., Young, G.M., 1982. Early Proterozoic climates and plate motions inferred from major element chemistry of lutite. Nature 299, 715-717.

Nesbitt, H.W., Young, G.M., 1989. Formation and diagenesis of weathering profiles. J. Geol. 97, 129-147.

Page, A.L., Miller, R.H., Keeney, D.R., 1982. Methods of Soil Analysis, Part 2. Chemical and Microbiological Properties. American Society of Agronomy and Soil Science Society of America, Madison, Wisconsin, USA.

Pimentel, D., 2006. Soil erosion: a food and environmental threat. Environ. Dev. Sustain. 8, 119-137.

Poesen, J., 2018. Soil erosion in the Anthropocene: research needs. Earth Surf. Process. Landforms 43, 64-84.

Renner, L.C., Hartmann, L.A., Wildner, W., Massonne, H.-J., Theye, T., 2011. A microanalytical approach to partition 365 coefficients in plagioclase and clinopyroxene of basaltic sills in Serra Geral Formation, Paraná Basin, Brazil. Rev. bras. Geociênc. 41 (2), 263-289.

Restrepo, J.D., Kettner, A.J., Syvitski, J.P.M., 2015. Recent deforestation causes rapid increase in river sediment load in the Colombian Andes. Anthropocene 10, 13-28.

Reusser, L., Bierman, P., Rood, D., 2015. Quantifying human impacts on rates of erosion and sediment transport at a landscape scale. Geology 43, 171-174.

Rietveld, H.M., 1969. A profile refinement method for nuclear and magnetic structures. J. of Applied Crystall. 2, 65-71.

Robert, M., Tessier, D., 1974. Méthode de préparation des argiles des sols pour des études minéralogiques. Ann. Agron. 25, 859-882.

Robinet, J., Minella, J.P.G., de Barros, C.A.P., Schlesner, A., Lücke, A., Ameijeiras-Mariño, Y., Opfergelt, S., Vanderborght, J., Govers, G., 2018a. Impacts of forest conversion and agriculture practices on water pathways in Southern Brazil. Hydrol. Process. $1-14$.

Robinet, J., von Hebel, C., Govers, G., van der Kruk, J., Minella, J.P.G., Schlesner, A., Ameijeiras-Marino, Y., Vanderborght, J., 2018b. Spatial variability of soil water content and soil electrical conductivity across scales derived from electromagnetic induction and time domain reflectometry. Geoderma 314, 160-174.

Schnitzer, M., Kodama, H., 1976. The dissolution of mica by fulvic acid. Geoderma 15, 381-391.

Schoonejans, J., Vanacker, V., Opfergelt, S., Ameijeiras-Mariño, Y., Christl, M., 2016. Kinetically limited weathering at low denudation rates in semi-arid climatic conditions. J. Geophys. Res. Earth Surf. 121.

Schoonejans, J., Vanacker, V., Opfergelt, S., Christl, M., 2017. Long-term soil erosion derived from in-situ ${ }^{10} \mathrm{Be}$ and inventories of meteoric ${ }^{10} \mathrm{Be}$ in deeply weathered soils in southern Brazil. Chem. Geol. 466, 380-388.

Shao, J., Yang, S., Li, C., 2012. Chemical indices (CIA and WIP) as proxies for integrated chemical weathering in China: inferences from analysis of fluvial sediments. Sediment. Geol. 265-266, 110-120.

Simonsson, M., Hillier, S., Öborn, I., 2009. Changes in clay minerals and potassium fixation capacity as a result of release and fixation of potassium in long-term field experiments. Geoderma 151, 109-120.

Unzué-Belmonte, D., Ameijeiras-Mariño, Y., Opfergelt, S., Cornélis, J.T., Barão, L., Minella, J., Meire, P., Struyf, E., 2017. Land use change affects biogenic silica pool distribution in a subtropical soil toposequence. Solid Earth 8, 737-750.

Van Oost, K., Govers, G., de Alba, S., Quine, A., 2006. Tillage erosion: a review of controlling factors and implications for soil quality. Prog. Phys. Geogr. 30 (4), 443-466.

Vanacker, V., von Blanckenburg, F., Govers, G., Molina, A., Poesen, J., Deckers, J., Kubik, P., 2007. Restoring natural vegetation reverts mountain erosion to natural levels. Geology 35, 303-306.

Vanacker, V., Bellin, N., Molina, A., Kubik, P.W., 2014. Erosion regulation as a function of human disturbances to vegetation cover: a conceptual model. Landsc. Ecol. 29 (2), 
293-309.

Velde, B., Meunier, A., 2008. Chapter 5 plants and soil clay minerals. In: The Origin of Clay Minerals in Soils and Weathered Rocks. 406 Springer-Verlag, Berlin.

Velde, B., Peck, T., 2002. Clay mineral changes in the morrow experimental plots, University of Illinois. Clay Clay Miner. 50, 364-370.

Vieira, B.C., Salgado, A.A.R., dos Santos, L.J.C., 2015. Landscapes and landforms of Brazil. In: World Geomorphological Landscapes Book Series. Springer, Dordrecht.
Vitousek, P., Chadwick, O.A., Matson, P., Allison, S., Derry, L.A., Kettley, L., Luers, A., Mecking, E., Monastra, V., Porder, S., 2003. Erosion and the rejuvenation of weathering-derived nutrient supply in an old tropical landscape. Ecosystems 6, 762-772.

Wilkinson, B.H., 2005. Humans as geologic agents: a deep-time perspective. Geology 33 (3), 161-164. 